\title{
Content-based ESL in a Sheltered Psychology Course: Input, Output and Outcomes
}

\author{
Sandra Burger
}

\begin{abstract}
According to Krashen (1983), subject matter language teaching satisfies the three requirements for second language acquisition of his input hypothesis, namely: large doses of comprehensible input, a low affective filter situation and a silent period. Is this enough for development of productive skills at advanced proficiency levels? Could the language teacher make the process more efficient and if so, how? In the 1984-85 school year, advanced students in the special section of Introductory Psychology open only to ESL students were offered an optional three-credit academic English "Reading-to-Writing" component during the second term. Ten out of sixteen students qualified and registered for this course. They practised different types of
\end{abstract}

writing and wrote critical reviews of simple articles from professional journals. At their request, they gave oral reports to the whole class.

This paper will compare the writing and non-writing students' results on various proficiency measures to those of students in regular language classes and examine students' comments on the course and their perception of progress made in the course. It will consider the role of active intervention by the language teacher to require, monitor and otherwise guide student output and explore the question of when input leads to output and when the practice of output is required in the refinement of speaking and writing skills.

Stephen Krashen (1981) in his well-known language acquisition theory has proposed that language learners be given large doses of comprehensible input in their target language, that is, input at a level of $i+1$, or just a little beyond the current level of the second language learner. In addition, this comprehensible input should be given in a non-stressful situation where the learners' affective filters are low. If these conditions are met, second language acquisition will take place (Krashen, 1985, p. 4). According to Krashen, students should also be allowed a silent period, just as first language learners usually have. This will result in speaking emerging on its own. Subject-matter language teaching, as in sheltered courses, meets the above requirements, although, as Krashen has noted "the beginning language student will not be able to participate since his language level will not be high enough to enable him to follow instruction" (1984, p. 63). He further notes that the goal of sheltered courses is "to produce students who can read and write well" $(1984$, p.63) and that "the way to achieve this is not to force speaking and writing but to provide massive 
amounts of comprehensible input. The ability to produce will be a result of this input" (1984, p. 63).

This article will describe an experiment where some students in a subject-matter language class were given extra practice in written and oral production in addition to the comprehensible input that all the students in the class receive. All students were tested for pre/post-gains on a variety of measures including written compositions. Their results were compared to those of control groups in regular language classes. These results along with students' comments on the course and their perception of progress made in the course will be considered in addressing the role of focussed reading activities for advanced students in a content-based course. Does this teaching strategy lead to gains in receptive skills in the second language? in production skills? Is writing practice a better strategy for teaching composition skills?

\section{Subject-Matter Language Teaching}

Krashen $(1981,1984)$ considers the language class to be the best place for beginning language learners to get the comprehensible input in the low affective filter context that they need for second language acquisition. The language class should bring students to intermediate language competence. At that point, they will be ready to cross the bridge between language classes and the real world. That bridge will be subject-matter language teaching. Students will learn real subject matter, thereby focussing on meaning and not on form, in the second language. Because no native speakers will be allowed in the class, the professor will be able to structure lectures to ensure comprehensible input. The second language learner, by interacting with the professor will negotiate meaning, thereby ensuring that the input is comprehensible. Furthermore, to keep the affective filter low, the course will not require a lot of production from the students in their second language. They and the professor will be given frequent feedback through short multiple choice or true/false quizzes. It will not be necessary to demand production because speaking will emerge by virtue of the students' being in contact with the comprehensible input in the second language. In addition, a language teacher will be assigned to each section to suggest ways of making the input comprehensible, to help students with language problems and to reduce their anxiety.

\section{History of the Subject-Matter Language Teaching Project}

The subject-matter language teaching courses at the University of Ottawa, a bilingual university, were set up to test Krashen's theories. For many reasons, Introductory Psychology was the ideal choice for the first experiment. In 1982, two sheltered sections of the second semester of 
Introductory Psychology were offered; one in English and the other in French. Before being admitted, students had to write the University's second language proficiency test, a general test of listening and reading comprehension with a multiple choice cloze subtest. ${ }^{1}$ Only intermediate language learners were admitted, i.e. those scoring between 45 and 70 per cent. ${ }^{2}$ In order to encourage students to risk taking a course in their second language, the Centre for Second Language Learning offered them credit in English or French if they passed the psychology course. A language teacher was assigned to each section and students received approximately twenty minutes of language-related instruction with the language teacher either before or after each lecture period. At first the role of the language teacher was not clear, because there could not be the usual teaching of grammar and practising of skills. As the experiment progressed, however, the role of the language teacher emerged as one of being first a facilitator, doing whatever was necessary to help students understand the subject-matter lecture and their textbook readings and encouraging the students to reduce their anxiety and, secondly, being a consultant to the subject-matter teacher, suggesting adjustments if necessary to ensure students' comprehension. The role of the language teacher was discussed more fully in Burger et al. (1984). The ESL course continued in this way for the next two years.

A study of the subject-matter language teaching experiment in 1984 (Edwards et al. 1984) reported that after only thirteen weeks (39 hours) of instruction, both the ESL and FSL sheltered class groups showed clear and significant gains in general proficiency on almost all measures used in the study. It was further shown that these gains were comparable to those of groups studying the second language in regular language classes. In addition, students' results in the psychology examinations were comparable to those of comparison first language classes taught by the same professors.

A study of the psychology professors' modifications in discourse to second language speakers revealed that, although there were ranges in variability from speaker to speaker, there were systematic deviations from the same professors' discourse to native speakers (Wesche and Ready 1985). Differences included speech rate, syntactic features, discourse features and non-verbal behaviour. Adjustments included simplification, well-formedness, greater formal explicitness, regularization and added redundancy.

\section{The Present Study}

In the 1984-85 school year, the English psychology sheltered course was expanded to a full, two-semester course. (This had been done in French the year before.) Because there were a number of advanced stu- 
dents, and because the course was going to run for two semesters, in the second semester, the Centre decided to offer a Reading-to-Writing credit course paired with the subject-matter course for those students with above $70 \%$ on the Proficiency Test. Thus, there would be subject-matter language teaching for intermediate students and the same subject-matter language teaching plus the Reading-to-Writing course for advanced students. Students registered in the Reading-to-Writing course would be required to do extra reading and writing assignments.

This situation presented the researchers with the opportunity to explore the role of comprehensible input versus practice in speaking and writing (output) in developing both receptive and productive advanced second language skills. With the sheltered-only group, the effect of comprehensible input only on students' L2 proficiency could be observed to see if "the ability to produce (would) result from (the provision of) massive amounts of comprehensible input" (Krashen 1984, p. 63). With the reading-to-writing group, the effect of extra writing practice on L2 proficiency could be measured to determine the effect of practice in output on students' second language proficiency to test the "comprehensible output hypothesis" suggested by Swain to explain the relatively poor grammar performance of immersion students (1985, p. 249). A series of tests administered to Grade 6 French immersion students indicated that in spite of 7 years of comprehensible input in the target language, their grammar performance was not equivalent to that of native speakers. Swain concluded that what was missing for the immersion students was not comprehensible input but comprehensible output. By comprehensible output, she means "output that extends the repertoire of the learner as he or she attempts to create, precisely and appropriately, the meaning desired" (1985, p. 252). In our experiment a comparison could be made of language gains for the sheltered-only group versus the sheltered-plus-extra-practice group.

\section{Subjects: Experimental (Sheltered Class) Group}

The experimental subjects were sixteen regular students at a high intermediate to advanced level of English proficiency who registered for the introductory psychology course which was offered in English. They formed a special sheltered section of the psychology course and had to meet certain requirements. The requirements included attending at least eighty per cent of the classes, doing all readings in English, taking frequent objective subject-matter tests in lieu of the term paper and mid-semester essay examination required by the regular sections, and completing all research tests and questionnaires. All students remained in the sheltered section both semesters and fulfilled all these requirements.

Ten of the sixteen students registered for the extra Reading-to-Writing 
credit course. They were advanced students with scores above $70 \%$ on the Proficiency Test. All ten students fulfilled the requirements for this extra credit course.

\section{Subjects: Second Language Comparison Groups}

The students in two ESL classes given by the University's Centre for Second Language Learning served as second language comparison groups. Their scores on the University's Proficiency Test were similar to those of the experimental group. Approximately half of them had already satisfied the University's minimum second language requirements and were thus taking the second language course on an elective basis. Their ESL classes were regular 4-skill ESL courses of three or four hours a week. The ESL comparison group consisted of seventeen students.

\section{Experimental Treatment (Sheltered Classes)}

In the first semester, all students in the sheltered course received approximately twenty minutes of language teaching either before or after the psychology lecture. In the language class, activities were mainly geared to aiding and checking students' comprehension of the psychology material being presented. Ways of interrupting the psychology professor politely to negotiate meaning were presented. New vocabulary was introduced before it was presented in lectures or readings. Students did various exercises designed to check their comprehension.

In the second semester, the optional Reading-to-Writing course began. Unfortunately, it was impossible to find a common time to meet for the extra course, so the language teacher had to use some of the general language class time for the special course and arranged to meet students individually each week for an additional 45 minutes per week. The requirements for the course were as follows:

\section{Reading to Writing (Advanced ESL)}

Open to all PSY $1200 \mathrm{~F}$ students who have scored $70 \%$ or more on the official English Proficiency Test.

I. Three one-page compositions exhibiting the following types of writing:

1) Definitions

2) Cause and result

3) Comparison and Contrast

II. Five critical reviews of articles from a recognized psychology journal.

( 2 pages maximum each)

III. A one-hour final examination in which free writing will be evaluated. 
Because only the language class time (approximately 20 minutes twice a week) was available, and because the language teacher thought all students in the sheltered course could benefit in their reading strategies from looking at different types of writing, the first four assignments were introduced in class time and the teacher met with students in the extra course individually to discuss their compositions. Thus the entire sheltered class received focussed instruction about written forms but only the students registered in the Reading-to-Writing course actually practised writing.

For the first three assignments, the class looked at the usual form of definitions, comparisons and contrasts and cause and effect relationships. Samples of the different types of writing were taken from the regular Reading-to-Writing textbook (Hauptman and Donegan 1983) and from the regular psychology textbook (Hilgard et al. 1979). All students did short exercises which required identifying relevant connectors, matching definitions with terms or analysing relationships such as cause and result in class. Those registered in the Reading-to-Writing credit course did extra assignments to practise the particular type of writing under study. For example, the second assignment was:

\section{ASSIGNMENT \#2: CAUSE AND RESULT}

I. Explain why one of Köhler's experiments with Sultan the chimpanzee is an example of learning through insight rather than through association. (Reference: Text p. 212)

or

Explain how Epstein's experiment with pigeons (Text p. 123) is an example of learning through insight rather than through association.

II. Show how the cognitive map theory explains the learning of the rats in the latest learning experiment conducted by Tolman and Honzik. (Text p. 213, 214)

The assignments were always related to what was being taught in the psychology course. The students found this type of assignment satisfying because it was real. It was important for the students to know something about these experiments, to know something about insight learning and learning by association rather than, as often happens in second language classes, having to compare two imaginary characters or two cities in which they have no interest.

As for the correction of errors in student assignments, the English teacher paid more attention to content and the overall organization of papers than to grammatical or spelling errors. The latter were corrected, however, and commented upon in a non-threatening manner. Although the 
literature seems to indicate that the correction of errors has no measurable effect on students' performance, (Semke 1984), the reasons for doing such corrections were first that students expect them and secondly that students just might be ready at that point to incorporate the correct form into their personal grammar.

The selection of articles for critical reviews was made with the help of the psychology professor and the research assistant. For four of the articles to be read and reviewed by the students, we chose one from the field of second language acquisition, a study done by researchers at the University of Ottawa and three papers, each representing one of the three main schools of psychology. From the school of psychoanalysis, an article attempting to prove Freud's theory of castration anxiety was selected. From social learning theory, students were assigned a description of experiments on monkeys which demonstrated the need for touch. Finally the article from Rogers' humanistic theory analysed and compared two of Rogers' therapy sessions 30 years apart. The choice for the fifth article for review was left to the students. A choice of about ten recent articles from Psychology Today was offered to them and they made their selection from these rather than finding their own articles.

The entire experimental class, both the sheltered-only students and the sheltered-plus-extra-practice group, looked at the typical form of experimental research articles, which usually have three parts, an introduction, a discussion of a particular experiment and a conclusion. The discussion of an experiment usually has two sections: collecting and manipulating the data (usually chronologically ordered) and then the results, usually some statistical information. The class also looked at two critical reviews from TESOL Quarterly and discussed the typical form of the critical review. Such reviews usually have an introduction discussing the need for such an experiment or the usefulness of the experiment, a discussion of what was done in the experiment and its results and finally, some comment on the conclusions of the experiment or the implications of the experiment. Of course, the students were only in first year psychology, so one could not expect a truly scholarly interpretation of the articles read. Nevertheless, they were usually able to appreciate some of the applications or implications of the experiments.

During the month of February, when the students were working their way through the critical reviews, a couple of students asked the language teacher if they were going to present the articles in class, since people were reading different articles and it would be interesting to learn about the other articles. The teacher thought it was a good idea, especially since the suggestion was student generated. Thus, it seemed justifiable to approach all the students in the reading-to-writing group with the idea. Not only did they all agree to do it, but seven out of ten agreed to have 
their presentations videotaped. Each student went over the presentation with the project's research assistant for content and the language teacher for accuracy and style before the class. The aim was to be sure the content was correct and to make sure that what the students would say would be comprehensible to the rest of the class. This also served to lower the anxiety level for the students because they felt confident about what they were going to say. The teacher later viewed the recorded presentation with the students in small groups to give them feedback.

For the final examination, students were asked to read an article written by Krashen (1983) on subject-matter language teaching. This article gave the theoretical background for our experiment and described the first year's experiment. Students were asked to summarize the article and comment from their own experience. Summaries were judged according to criteria of completeness, accuracy of comprehension of concepts and organization along with linguistic criteria such as language use, range of vocabulary and mechanics. Comments were judged according to the linguistic criteria.

\section{Proficiency Measures}

A proficiency test for advanced students in the social sciences, the Social Sciences English Proficiency Test, was administered to students in the subject-matter language teaching course and to control groups from regular ESL classes in September and again in March. This test has been field tested extensively and been found to discriminate very well among higher proficiency students.

The test consisted of the following sub-tests: a listening comprehension exercise where students listened to a passage in the target language and answered comprehension questions in their native language; $a$ dictation test with increasingly longer phrases read twice for dictation; a translation task with two excerpts from a passage to be translated from the target language into the native language; a cloze passage (open-ended); and a writing task where students wrote a letter to the editor of a newspaper in response to a newspaper article. The translation was marked for completeness and comprehensibility and not for style. The dictation was corrected so as to give credit for responses showing clear understanding of the passage. It was thus a precise test of listening comprehension. The compositions were all marked by two trained markers without the names of students on them or any indication of whether they were pre- or post-tests. The grid used for correcting the composition, adapted from Jacobs et al (1981), is reproduced in Appendix 1.

T-tests (Table 1) were done to measure the gains for each group separately. An ANCOVA test (analysis of covariance) was done in order to see whether there was a difference between the gains made by the two groups. 


\section{Results}

Table 1

English (Full Year) 1984-85

$\mathrm{N}($ Exp. $)=16 . \quad \mathrm{N}($ Control $)=17$.

$\underline{\text { T-Test Pre-Post Means by Group }}$

\begin{tabular}{|c|c|c|c|c|}
\hline \multicolumn{3}{|c|}{ EXPERIMENTAL } & \multicolumn{2}{|c|}{ CONTROL } \\
\hline Variable & $\begin{array}{l}\text { Mean } \\
\text { Pre- }\end{array}$ & $\begin{array}{l}\text { Mean } \\
\text { Post- }\end{array}$ & $\begin{array}{c}\text { Mean } \\
\text { Pre- }\end{array}$ & $\begin{array}{l}\text { Mean } \\
\text { Post- }\end{array}$ \\
\hline Total Proficiency & $\begin{array}{c}110.18 \\
(\mathrm{~N}=11)\end{array}$ & $145.32^{* * *}$ & $\begin{array}{c}126.73 \\
(N=15)\end{array}$ & $147.3^{* * *}$ \\
\hline Listening & 3.31 & $4.5^{*}$ & 4.29 & 4.5 \\
\hline Dictation & 55.00 & $72.75 * * *$ & 63.29 & $75.06 * * *$ \\
\hline Translation & $\begin{array}{r}24.27 \\
\mathrm{~N}=11\end{array}$ & $38.09 * * *$ & 29.00 & 34.07 \\
\hline Cloze & 27.97 & $32.25 * * *$ & 29.82 & $33.26^{* *}$ \\
\hline Content & 3.77 & $4.67 * *$ & 4.12 & 4.24 \\
\hline Organization & 4.07 & $4.62^{*}$ & 4.47 & 4.24 \\
\hline Language Use & 3.87 & $4.73 * *$ & 4.21 & 4.35 \\
\hline Mechanics & 4.50 & $5.23^{*}$ & 4.79 & 4.88 \\
\hline Vocabulary & 4.10 & $4.90^{*}$ & 4.29 & 4.50 \\
\hline Total Composition & 20.30 & $24.50 * *$ & 21.88 & 22.47 \\
\hline
\end{tabular}

Significant differences are based on T-Tests for correlated data.

$$
\begin{gathered}
*=\mathrm{p}<.05 \\
* *=\mathrm{p}<.01 \\
* * *=\mathrm{p}<.001
\end{gathered}
$$

Unfortunately, complete pre- and post-test scores were not available for all subjects on all sub-tests. Nevertheless, it can be seen from Table 1 that students in the regular language classes made significant gains in general proficiency and in the dictation and cloze sub-tests. Students in the experimental course, including both the sheltered and sheltered-plus-extra-practice sub-groups also made significant gains in general proficiency and in all sub-tests. On the composition measure only the experimental group made significant gains on all scoring criteria. The ANCOVA test did not show significant differences between the two groups, although trends 
favoured the experimental group in general proficiency and in the organization score of the composition subtest. The results enable us to conclude that students with a full-year course of subject-matter language teaching will make as great if not greater language gains than students in a regular language class, replicating the findings of other studies of these classes (Edwards et al, 1984, Hauptman et al. in press).

In an attempt to assess the value of practice in improving students' writing, the scores of sheltered-only students were compared with those of the sheltered-plus-extra-practice groups.

The results showed no significant differences in gains between the two groups. Both groups made significant gains in general proficiency, but T-tests revealed that the students who did not take the writing course actually showed a significant difference between pre- and post-composition measures more frequently than those students who took the writing course. This is perhaps explained by the fact that gains are more difficult to demonstrate at higher proficiency levels. Furthermore, the numbers in the two sub-groups for whom full data were available were very small. However, the findings are interesting in that they suggest that focussed reading rather than actual writing practice may have accounted for gains in writing skills. The only significant pre-post gain for the extra practice group was in language usage.

\section{Discussion}

Krashen (1985a, p. 115) maintains that the act of writing practice will not cause language acquisition, but only cognitive development. On the other hand, Swain's output hypothesis, (1985) suggests the need for output in improving students' second language performance. She says that the most useful situations for comprehensible output are interactions where there has been a communication breakdown and the learner, having received some negative feedback, is pushed to use alternate means to get his or her meaning across $(1985$, p. 248$)$. Further, producing the target language may even force the learner to pay attention to the means of expression needed in order to convey the intended meaning clearly. She suggests that the contributions of comprehensible output are, in addition to forcing the learners to move from semantic processing to syntactic processing, to provide for meaningful use of one's language resources, and provide an opportunity to test hypotheses. It is the first function which is of great interest with regard to the present study. In the study of different types of writing and indeed in the language classes where the class looked at form, the language teacher was encouraging the learners to analyse language forms and patterns rather than only to process meaning. It should be borne in mind that all students received the same type of teaching in 
class. The difference for the writing students was that they read five more articles than the rest of the class, wrote a lot, concentrating on specific skills, gave an oral presentation and had individual weekly consultations with the language teacher. They didn't sacrifice anything in terms of class work. They got more and yet didn't make significantly greater gains in the pre-post measure of composition other than in language use. Could it be, as Krashen suggests, (1985, p. 72) that comprehensible input is enough to ensure improvement in writing, or does comprehensible output foster greater gains in language use than just comprehensible input, as Swain suggests? No firm conclusion can be drawn from the small sample of this study. The jury is still out on this important issue and more research must be conducted.

There is, however, another factor in this question, and that is the students' perception of the whole exercise. Students in all courses at the University of Ottawa are invited to comment on courses they have taken as part of teacher evaluations done near the end of courses and passed on to teachers after final marks have been determined. Only the comments of sheltered students were available to the researcher. Typical comments follow.

It appears from these comments that the writing and speaking practice acted as a confidence builder for the students. Here are student A's written comments:

I learned a lot of things and in particular, the way of confidence and satisfaction of myself with the second language challenges . . .

Also some students who were not in the writing group felt that they were missing something and in written comments at the end of the course expressed feelings like these:

I find that we should be more insistant to talk during the class. I improved a lot my reading and vocabulary but not my speech because I never have to talk about psychology in English . . .

Student B.

and student $\mathrm{C}$ :

"Mais j'aurais aimé pour améliorer mon anglais avoir eu à faire 2 ou 3 travaux écrits en anglais." (But in order to improve my English, I would have liked to have had to do 2 or 3 written assignments in English.)

In terms of oral production, a skill which was not tested on our preand post-test, the language teachers in all the subject-matter language classes noticed that there seems to be a barrier to cross from the silent period to production. Indeed, speaking seems to emerge on its own, as 
Krashen has suggested, and when it does, more and more speaking tends to occur. Student D commented:

My first reaction was that I was really afraid of listening to an English professor. But I discovered that it was not that hard to understand. Then I tried to ask questions and started to enjoy participating in the class discussion. Now outside, in everyday life, I really want to use my second language and use the vocabulary and expressions I learned in class, they are in my mind, unconsciously. . .

A current area of research at the University of Ottawa is the development of communicative exercises for the sheltered subject-matter language courses, activities where there is an information gap between one student and another and the two students must talk to each other to get the required information (Johnson and Morrow, 1981).

\section{Conclusion}

Results of this study suggest that the addition of extra reading and writing practice in the form of a credit course linked to a sheltered subjectmatter language teaching course may not be necessary to ensure gains in second language proficiency. Nonetheless, if students are sufficiently advanced to be ready for corrections and polishing, and if the correcting and polishing are done in a reassuring environment, the extra practice cannot harm their progress and can lead to a greater sense of confidence in the students and a feeling of satisfaction with their efforts at learning a second language.

\section{NOTES}

1. The Proficiency Test's K-R20 reliability was .98 .

2. Later the minimum language proficiency admission score was raised to 50 because it was discovered that if students were too low in second language proficiency, they would have difficulty understanding the lectures and texts.

\section{REFERENCES}

Burger, S., M. Chrétien, M. Gingras, P. Hauptman, and M. Migneron. (1984). Le rôle du professeur de langue dans un cours de matière académique en langue seconde. The Canadian Modern Language Review 41(2), 397-402.

Edwards, H., M.B. Wesche, S.D. Krashen, R. Clément, and B. Krudenier. (1984). Second language acquisition through subject-matter learning: A study of sheltered psychology classes at the University of Ottawa. The Canadian Modern Language Review 41(2), 268-282.

Hauptman, P., M. Wesche, and D. Ready. (in press). Second language acquisition through subject-matter learning: A follow-up study at the University of Ottawa. Language Learning. 
Hauptman, P. and F. Donegan. (1983). Reading to Writing, Ottawa: Unpublished Manuscript.

Hilgard, E.R., R.L. Atkinson, and R.C. Atkinson. (1979). Introduction to Psychology. New York: Harcourt, Brace and Jovanovich Inc.

Jacobs, H., S. Zinkgraf, D. Wormuth, V. Hartfiel, and J. Hughey. (1981). Testing English Composition: A Practical Approach. Rowley, Mass.: Newbury House Publishers, Inc.

Johnson, K. and K. Morrow. (1981). Communication in the Classroom. Essex, England: Longman.

Krashen, S.D. (1985a). Inquiries and Insights. Hayward, Ca.: Allemany Press.

Krashen, S.D. (1985b). The Input Hypothesis: Issues and Implications. London: Longman.

Krashen, S.D. (1984). Immersion: Why it works and what it has taught us. Language and Society 12, Winter 1984, 61-64.

Krashen, S.D. (1983). From the classroom to the real world: Solving the transition problem. CSALT Bulletin.

Krashen, S.D. (1981). The fundamental pedagogical principle in second language teaching. Studio Linguistica 35(1-2), 50-70.

Semke, H.D. (1984). Effects of the red pen. Foreign Language Annals 17, 3, 195-202.

Swain, M. (1985). Communicative competence: Some roles of comprehensible input and comprehensible output in its development. In S.M. Gass, and C.G. Madden, (Eds.) Input in Second Language Acquisition, 235-254. Rowley, Mass.: Newbury House Publishers, Inc.

Wesche, M.B. and D. Ready. (1985). Foreigner talk in the university classroom. In S.M. Gass, and C.G. Madden (Eds.) Input in Second Language Acquisition, 89-114. Rowley, Mass.: Newbury House Publishers, Inc.

\section{ACKNOWLEDGEMENTS}

A shorter version of this article was presented at TESOL ' 86 in Anaheim, California. The author wishes to thank Marjorie Wesche, Doreen Ready, Philip Hauptman, Hedy McGarrell, Jill Doherty and Patricia Raymond for their encouragement and feedback on earlier versions of this article. In addition thanks are owed to all participants in the project, the students, the psychology professors Henry Edwards and Rick Markow and Doreen Ready, the research assistant at the Centre for Second Language Learning.

\section{THE AUTHOR}

Sandra Burger is a Language Teacher at the Centre for Second Language Learning, University of Ottawa. She has been involved in Subject-Matter Language Teaching since 1982. 
APPENDIX 1

Writing Scale

\begin{tabular}{|c|c|c|c|}
\hline \multirow{7}{*}{$\begin{array}{l}\mathrm{C} \\
\mathrm{O} \\
\mathrm{N} \\
\mathrm{T} \\
\mathrm{E} \\
\mathrm{N} \\
\mathrm{T}\end{array}$} & 7 & Excellent: & $\begin{array}{l}\text { Knowledgeable, substance, thorough development of } \\
\text { thesis. }\end{array}$ \\
\hline & 6 & Very Good: & $\begin{array}{l}\text { Relevant to assigned topic (often approaching bilingual } \\
\text { competence). }\end{array}$ \\
\hline & 5 & Good: & $\begin{array}{l}\text { Systematic development of topic with well-structured main } \\
\text { and subordinate themes and relevant supporting detail. }\end{array}$ \\
\hline & 4 & Average: & $\begin{array}{l}\text { Mostly relevant to topic but lacks detail and supporting } \\
\text { statements (slight limitation of style and mastery of } \\
\text { appropriate idiom). }\end{array}$ \\
\hline & & Fair: & $\begin{array}{l}\text { May lack interest but basic message gets through. Limited } \\
\text { knowledge of subject. }\end{array}$ \\
\hline & 2 & Poor: & $\begin{array}{l}\text { Backtracks and may repeat. Basic theme is conveyed but } \\
\text { imperfectly. }\end{array}$ \\
\hline & 1 & Very Poor: & $\begin{array}{l}\text { A string of sentences rather than an essay; or not enough } \\
\text { to evaluate. Does not show knowledge of subject. }\end{array}$ \\
\hline \multirow{7}{*}{$\begin{array}{l}\mathrm{O} \\
\mathrm{R} \\
\mathrm{G} \\
\mathrm{A} \\
\mathrm{N} \\
\mathrm{I} \\
\mathrm{Z} \\
\mathrm{A} \\
\mathrm{T} \\
\mathrm{I} \\
\mathrm{O} \\
\mathrm{N}\end{array}$} & 7 & Excellent: & $\begin{array}{l}\text { Fluent expression, ideas clearly stated and supported, } \\
\text { concise. }\end{array}$ \\
\hline & 6 & Very Good: & Clear and logical, cohesive. \\
\hline & 5 & Good: & Loosely organized but main ideas stand out. \\
\hline & 4 & Average: & Logical but incomplete sequencing, somewhat choppy. \\
\hline & 3 & Fair: & Structure of presentation will lack clarity, non-fluent. \\
\hline & 2 & Poor: & Lacks logical structure and use of discourse markers. \\
\hline & 1 & Very Poor: & No organization, does not communicate. \\
\hline
\end{tabular}




\begin{tabular}{|c|c|c|c|}
\hline \multirow{7}{*}{$\begin{array}{c}\text { M } \\
\text { E } \\
C \\
\text { H } \\
\text { A } \\
\text { N } \\
\text { I } \\
\text { C } \\
\text { S }\end{array}$} & 7 & Excellent: & Mastery of conventions. \\
\hline & 6 & Very Good: & $\begin{array}{l}\text { Few errors of spelling, punctuation, capitalization, } \\
\text { paragraphing. }\end{array}$ \\
\hline & 5 & Good: & $\begin{array}{l}\text { Some errors of spelling, punctuation, capitalization, } \\
\text { paragraphing. }\end{array}$ \\
\hline & 4 & Average: & More frequent errors but meaning not obscured. \\
\hline & 3 & Fair: & Meaning sometimes confused or obscured. \\
\hline & 2 & Poor: & $\begin{array}{l}\text { Meaning generally confused or obscured. Basic } \\
\text { punctuation conventions followed. }\end{array}$ \\
\hline & 1 & Very Poor: & $\begin{array}{l}\text { No mastery of convention. Dominated by errors of } \\
\text { spelling, punctuation, capitalization and paragraphing. }\end{array}$ \\
\hline \multirow{7}{*}{$\begin{array}{l}\text { V } \\
\text { O } \\
\text { C } \\
\text { A } \\
\text { B } \\
\text { U } \\
\text { L } \\
\text { A } \\
\text { R } \\
\text { Y }\end{array}$} & 7 & Excellent: & $\begin{array}{l}\text { Sophisticated range, appropriate register, word form } \\
\text { mastery. }\end{array}$ \\
\hline & 6 & Very Good: & $\begin{array}{l}\text { Effective word/idiom choice and usage often approaching } \\
\text { bilingual competence. }\end{array}$ \\
\hline & 5 & Good: & Adequate range, occasional errors. \\
\hline & 4 & Average: & $\begin{array}{l}\text { Some limitation in the range of language. Reasonably } \\
\text { accurate lexis, meaning not obscured. }\end{array}$ \\
\hline & 3 & Fair: & $\begin{array}{l}\text { Limited range, meaning occasionally confused or } \\
\text { obscured. }\end{array}$ \\
\hline & 2 & Poor: & Meaning often confused or obscured, frequent errors. \\
\hline & 1 & Very Poor: & $\begin{array}{l}\text { Restricted lexis, little knowledge of English vocabulary, } \\
\text { idioms, word form; or not enough to evaluate. }\end{array}$ \\
\hline
\end{tabular}

\begin{tabular}{|c|c|c|c|}
\hline & 7 & Excellent: & Mastery of appropriate and concise English. \\
\hline & 6 & Very Good: & $\begin{array}{l}\text { Few errors of agreement, tense, number, word order/ } \\
\text { function, articles, pronouns, prepositions. }\end{array}$ \\
\hline $\begin{array}{l}\mathrm{L} \\
\mathrm{A} \\
\mathrm{N}\end{array}$ & 5 & Good: & $\begin{array}{l}\text { Generally accurate and appropriate language, layout and } \\
\text { style. Minor problems in complex constructions. }\end{array}$ \\
\hline $\begin{array}{l}\text { G } \\
\text { U } \\
\text { A } \\
\text { G }\end{array}$ & 4 & Average: & $\begin{array}{l}\text { Quite a few errors of agreement, tense, number, word } \\
\text { order/function, articles, pronoun, prepositions but } \\
\text { meaning not confused or obscured. }\end{array}$ \\
\hline $\begin{array}{l}\mathrm{E} \\
\mathrm{U} \\
\mathrm{S} \\
\mathrm{E}\end{array}$ & 3 & Fair: & $\begin{array}{l}\text { Some problems in simple/complex construction. Frequent } \\
\text { errors of agreement, tense, number, word order/function, } \\
\text { articles, pronouns, prepositions. Meaning somtimes } \\
\text { confused or obscured. }\end{array}$ \\
\hline & 2 & Poor: & Frequent errors. Meaning often confused or obscured. \\
\hline & 1 & Very Poor: & Dominated by errors. \\
\hline
\end{tabular}

